\title{
Behaviour of stocked and naturally recruited European eels during migration
}

\author{
Håkan Westerberg ${ }^{1, *}$, Niklas Sjöberg ${ }^{1,2}$, Ingvar Lagenfelt $^{3}$, Kim Aarestrup ${ }^{4}$, \\ David Righton ${ }^{5}$ \\ ${ }^{1}$ Swedish University of Agricultural Sciences (SLU), Institute of Freshwater Research, 17893 Drottningholm, Sweden \\ ${ }^{2}$ Department of Ecology, Environment and Plant Sciences, Stockholm University, 10691 Stockholm, Sweden \\ ${ }^{3}$ The County Administrative Board of Västra Götaland, 40340 Göteborg, Sweden \\ ${ }^{4}$ Technical University of Denmark (DTU), National Institute of Aquatic Resources, Vejlsøvej 39, 8600 Silkeborg, Denmark \\ ${ }^{5}$ Centre for Environment, Fisheries, and Aquaculture Science (CEFAS), Pakefield Road, Lowestoft NR33 0HT, UK
}

\begin{abstract}
One objection to the stocking of translocated eels as a management measure for the European eel Anguilla anguilla $L$. is that these eels may lack the ability to find their way back to the spawning area in the Sargasso Sea because the translocation will confuse their imprinted navigation. We undertook a series of tagging experiments using satellite tags, data storage tags and acoustic tags to test the hypothesis that eels translocated $1200 \mathrm{~km}$ from the UK to Sweden differed in their ability to migrate compared to naturally recruited eels. Eels to be tagged were caught in 2 locations, one with a record of eel stocking for more than $20 \mathrm{yr}$ and with a series of barriers to upstream migration and another in a river with only natural immigration and without barriers to upstream migration. In the first year, the naturally recruited and stocked eels were released in a fjord where the initial escapement behaviour could be monitored by acoustic tagging in addition to using archival tags to track the subsequent marine migration. In the second year, eels were tagged with archival or satellite tags and released on the open coast, and only their marine migration was investigated. Eels were tracked more than $2000 \mathrm{~km}$ along a route that, after leaving the Skagerrak, followed the Norwegian Trench to the Norwegian Sea, turned south and west along the Faroe-Shetland channel before emerging into the Atlantic Ocean, and then continued west. There were no statistically significant differences in estuarine or oceanic behaviour regarding route, swimming speed and preferred swimming depth between stocked and naturally recruited eels. These results provide the first empirical evidence of a Nordic migration route and do not support the hypothesis that a sequential imprinting of the route during immigration is necessary for adequate orientation or behaviour during the adult spawning migration.
\end{abstract}

KEY WORDS: Eel management plan · Anguilla anguilla - Translocation · North Atlantic . Electronic tags

Resale or republication not permitted without written consent of the publisher

\section{INTRODUCTION}

The dramatic decrease in recruitment of the European eel Anguilla anguilla L. during the last $30 \mathrm{yr}$ (Dekker 1998, 2008, ICES 2011a) has motivated the European Union (EU) to introduce a regulation establishing measures for the recovery of the stock (Council Regulation No. 1100/2007). This regulation requires the member states to prepare eel management plans (EMPs) for all eel habitats. The objective of each EMP as stated in Article 2 of the regulation is to reduce anthropogenic mortalities 'so as to permit with high probability the escapement to the sea of at least $40 \%$ of the biomass of silver eel relative to the best estimate of escapement that would have existed if no anthropogenic influences would have impacted 
the stock'. The regulation lists some possible management measures that could be used in an EMP, including the trapping and transport (hereafter termed 'stocking') of surplus glass eels from one EU country to another.

Stocking has taken place for more than a century with the goal of increasing the yield of local fisheries. As such, several studies document the survival of stocked eels during their growth stage (Wickström et al. 1996, Huertas \& Cerdà 2006) and the effects of stocking on the output of the fishery (EIFAC 1982, Rosell et al. 2005). In general, stocking has a beneficial effect on fishery yields, and it seems reasonable to conclude that stocking, in combination with greater control of fishing activity, could lead to higher silver eel escapement values.

In previous years, stocking has been considered problematic on several accounts, e.g. risk of spreading of disease and loss of genetic variation because of geographically differentiated gene expression (Pujolar et al. 2006, Als et al. 2011). Crucially, the ability of stocked eels to migrate back to their natal spawning area has been questioned, primarily based on a series of tagging experiments in the Baltic that aimed to examine the effect of stocking on migration success (Westin 1990, 1998, 2003). These studies concluded that stocked eels lacked the orientation mechanism necessary to locate the outlet to the Baltic Sea and, consequently, that their contribution to recruitment is null. More recent experiments in a German river at the Baltic coast have shown that stocked eels also have an initial delay to their migration, which was attributed to their stocked origin (Prigge et al. 2013). The underlying assumption of these studies is that larval eels imprint the migration route from the Sargasso Sea to their growth habitat, possibly by using a magnetic map (Svedäng \& Gipperth 2012), and then retrace this route when returning to spawn as adults. Eels that either do not have the full route imprinted on them or have a different route imprinted than the one they should take are assumed to have no value to the spawning stock. To date, however, no studies have been undertaken to examine this hypothesis.

Despite the criticism and uncertainty, stocking has become a major, if not the primary, measure in many national EMPs because it allows compliance with eel regulation targets without severe cuts in fishing effort or changes in catchment management. The advice from ICES is that 'When stocking to maximize output from the limited supply of glass eel currently available, an estimation of the prospective net benefit to silver eel escapement, to the extent possible, should be made prior to translocation for stocking' (ICES 2011b, p. 3). In Sweden in particular, stocking of glass eels (typically from the River Severn in England) has been used for many years in many rivers to help increase fisheries yield, and stocking efforts are well documented in a national database. Consequently, it is possible to identify rivers that are populated with predominantly stocked or naturally recruited eels and, therefore, to test the hypothesis that translocated and stocked eels differ from naturally recruited eels in their ability to navigate and migrate. Here, we describe the results of a 2 yr telemetry study of the marine migratory behaviour of eels originating from stocked and unstocked rivers and present the evidence for differences in migration route and speed between them. Additional tables (S1-S5) and a figure (S1) that are related to material, methods and acoustic tagging data are provided in the Supplement at www.int-res.com/articles/suppl/m496p145_supp.pdf

\section{MATERIALS AND METHODS}

\section{Origin of eels}

Stocking is widespread and not always well documented. The tendency for eels to disperse and the long period of time between stocking and subsequent silver eel escapement makes it almost impossible to find with certainty silver eels that are of stocked or naturally recruited origin. However, all eel stocking that has been undertaken in Sweden using government funding or as part of a license condition for a hydroelectric power plant is registered in a central database, thus providing a guide to those rivers likely to be dominated by stocked eels. We selected silver eels from 2 locations in that database, the River Enningdal and the River Ätran (Fig. 1). The Enningdal represented a river that in all likelihood contained only eels that were naturally recruited. This is because the river has no barriers to upstream migration, and there are no records of stocking into this river. In addition, the commercial eel fishery in this area is limited, making unreported, illegal stocking very unlikely (P. O. Wahrnberg pers. comm.). The risk of contamination by stocked eels at this locality was therefore considered extremely low. Eels from this river were captured in a silver eel trap in the commercial fishery in Kynne älv in the River Enningdal drainage area. In contrast, the River Ätran has been heavily stocked since 1983 as a compensation 


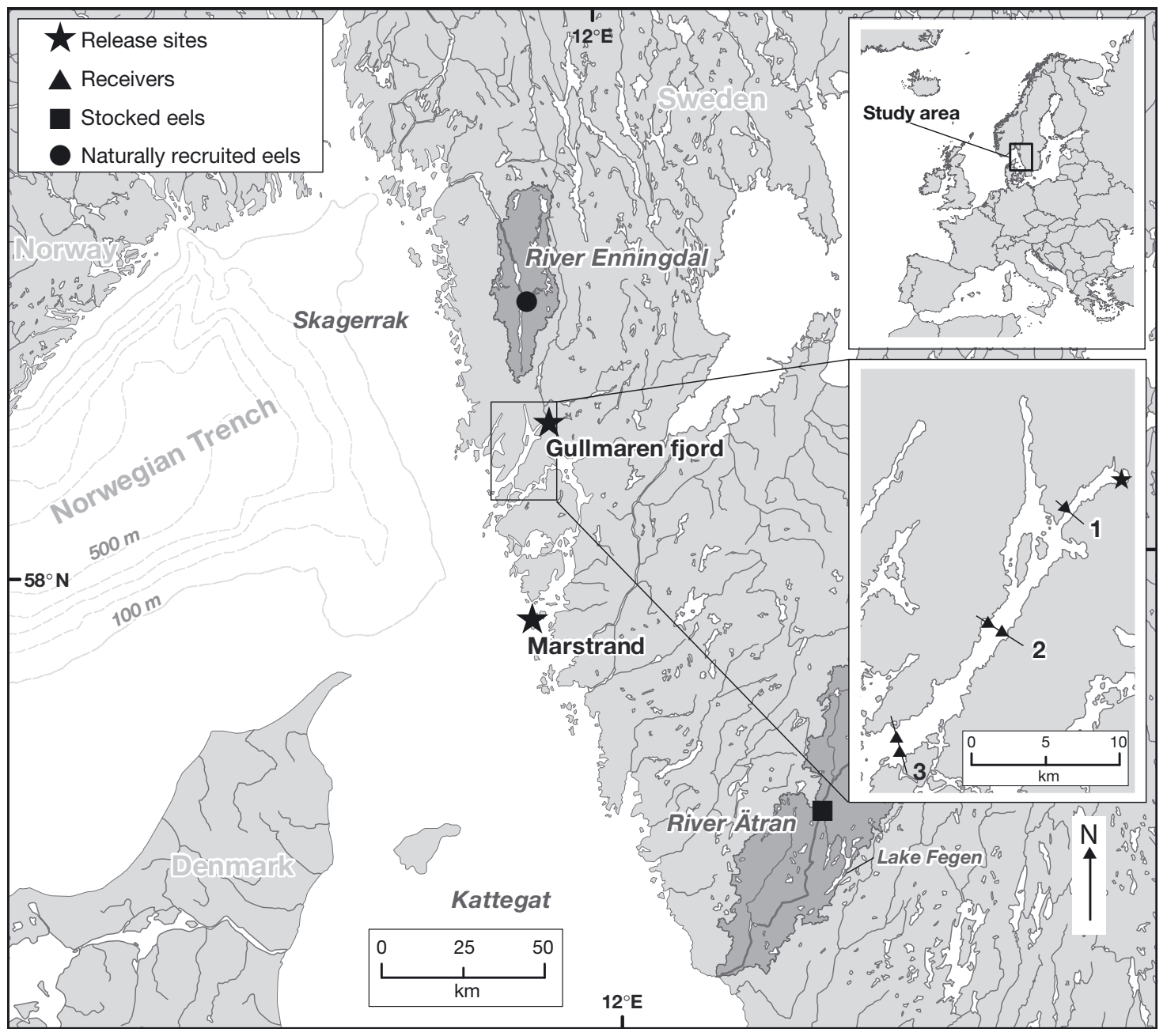

Fig. 1. Capture sites and release sites for the experiments in 2010 and 2011. The lower inset shows the positions of acoustic listening stations in the Gullmaren fjord. The drainage areas of the rivers Enningdal and Ätran are shown in a darker shade of grey. The numbers in the inset of the Gullmaren fjord refer to the transect numbers

for the removal of eel ladders at hydroelectric dams. The capture site was at the outlet from Lake Fegen, upstream of 7 dams, where since 1990 all officially recorded stocking has been made using from 2000 to 10000 imported and quarantined glass eels per year from the River Severn in England (Thörne \& Carlsson 2004). However, approximately 6000 bootlace eels, caught somewhere on the Swedish west coast (i.e. stocked origin but short transfer), were stocked in Lake Fegen in 1988 and 1989 (Thörne \& Carlsson 2004), and some private and unrecorded stocking of approximately 200 bootlace eels, also caught on the Swedish west coast, is known to have taken place in a lake connected to Lake Fegen each year since 2000 (I. Alenäs pers. comm.). Thus, while there was a possibility that a minority of eels in the River Ätran would originate from Skagerrak or Kattegatt, all eels captured in this river were of stocked origin, and the majority were translocated as glass eels. Eels from this river were caught in a Wolf trap in Mölneby, near the outlet of Lake Fegen, approximately $80 \mathrm{~km}$ from the river mouth.

To validate the origin of eels in these rivers, 10 reference eels from each capture location were sacrificed, and their otoliths were removed. Age readings were undertaken by counting winter zones in the otoliths (Svedäng et al. 1998). The ages varied between 15 and 21 yr for the Enningdal eels and between 15 and $22 \mathrm{yr}$ for the Ätran eels. The strontium:calcium ratio of one of the otoliths from each eel was analysed using particle-induced X-ray emission spectrometry ( $\mu$ PIXE, Malmqvist et al. 1993) at the Lund Nuclear Microprobe Laboratory. The analysis showed that all 10 of the individuals from Enningdal 
Table 1. Number of eels tagged and type of tag by year and capture site. Eels from the River Enningdal are of naturally recruited origin, and those from the River Ätran are of stocked origin. e-DST = externally attached data storage tag, i-DST = implanted data storage tag, PSAT = externally attached pop-up satellite tag

\begin{tabular}{|lcccc|}
\hline Capture site & e-DST & $\begin{array}{c}\text { i-DST }+ \\
\text { acoustic tag }\end{array}$ & PSAT & Total \\
\hline River Enningdal & & & & \\
2010 & 10 & 15 & 0 & 25 \\
2011 & 17 & 0 & 7 & 24 \\
River Ätran & & 15 & 0 & 25 \\
2010 & 10 & 0 & 8 & 25 \\
2011 & 17 & 30 & 15 & 99 \\
Total & 54 & & & \\
\hline
\end{tabular}

had spent time in salt and brackish water as juveniles (i.e. were of naturally recruited origin), while 8 of the Ätran eels had been transferred directly to freshwater as glass eels (i.e. were of stocked origin). By back-calculating from the ages of the sampled eels, the corresponding period of stocking was found to have been between 1988 and 1997, during which time 80000 glass eels and 8000 bootlace eels (equivalent to approximately 18000 glass eels if the mortality until the age of stocking is taken into account, Dekker 2012) were stocked. The expected proportion of eels stocked as glass eels was therefore $82 \%$, which agrees with the analysis of the otoliths.

\section{Eel tagging and release}

Captured eels (minimum $75 \mathrm{~cm}$ ) that were classified as silver eels were sorted and accumulated up to 3 wk prior to tagging in each of the 2 study systems. From these, a subset of 99 silver eels was selected to be tagged during the $2 \mathrm{yr}$ of the experiment (Table 1 ). All eels were large females. The overall means and standard deviations of length were $881 \pm 55 \mathrm{~mm}$ for River Ätran eels and $940 \pm 80 \mathrm{~mm}$ for Enningdal eels (2-way ANOVA, site effect, $F_{1,95}=18.6, \mathrm{p}<0.05$, Table S1 in the Supplement at www.int-res.com/ articles/suppl/m496p145_supp.pdf). However, the average length or weight of tagged eels did not differ significantly between the capture sites within each year (2-way ANOVA, year $\times$ site interaction, $F_{1,95}=$ 3.7 for length and $F_{1,95}=1.01$ for weight, $\mathrm{p}>0.05$ in both cases, Table S1 in the Supplement). The maturity of each eel was judged by 2 indices, the ratio between eye area and body length (BL) (Pankhurst 1982) and the ratio between the length of the pectoral fin and BL (Durif et al. 2005). According to those indices, all eels were in the silver eel stage. The mean Pankhurst index of the Enningdal and Ätran eels did not differ significantly within each year (2-way ANOVA, year $\times$ site interaction, $F_{1,95}=0.456, \mathrm{p}>$ $0.05)$, while the fin index was significantly higher in 2010 for the Enningdal eels but lower in 2011 (2-way ANOVA, year $\times$ site interaction, $F_{1,95}=5.3, \mathrm{p}<0.05$, Table S1 in the Supplement).

Each year, equal numbers of eels from each river were tagged with internal or external electronic tags (Table 1). Four types of tags were used in the experiments. Pop-up satellite tags (PSATs, X-tags) were supplied by Microwave Telemetry (www.microwave telemetry.com); these tags transmit depth and temperature data with, at best, a 15 min sampling rate. Data storage tags (DSTs, G5 long-life tags) were supplied by CEFAS Technology (www.cefastechnology. co.uk) and have incompressible floats to make them buoyant. They were configured for either internal implantation (i-DSTs) or external attachment (e-DSTs) and were programmed to record depth data every $30 \mathrm{~s}$ and temperature data every $120 \mathrm{~s}$. Acoustic tags used in 2010 were supplied by Thelma Biotel (www.thelma biotel.com) and transmitted a signal every 20 to $50 \mathrm{~s}$. Further details of tag type and specifications are given in Table S3 in the Supplement.

Eels were tagged under anaesthesia using metomidate (d1-1-(1-phenylethyl)-5-(metoxycarbonyl) imidazole hydrochloride) at a concentration of $40 \mathrm{mg} \mathrm{l}^{-1}$ for approximately 6 min. For implantation, the i-DSTs and acoustic tags were pushed through a small incision in the body cavity that was subsequently closed with independent single sutures (Thorstad et al. 2013). All external tags were attached in front of the dorsal fin using a 3-point attachment. Surgery took approximately $7 \mathrm{~min}$, with time to recovery of approximately the same duration. Eels were released in the evening of the day they were tagged. A detailed description of the surgery and tagging methods can be found in Thorstad et al. (2013) and Økland et al. (2013).

Eels from both rivers were tagged with internal or external electronic tags, as detailed in Table 1, and released on consecutive days in October, near the time of peak silver eel escapement in this part of Sweden. In 2010, the release was made innermost of the southernmost branch of the Gullmaren fjord, and in 2011, the release was made off the coast at Marstrand (Fig. 1). The first experiment in 2010 was designed to enable assessment of both the downfjord and oceanic migration, and hence eels were double-tagged with i-DSTs and with identificationcoded acoustic tags, making it possible to follow their 
progress in the fjord using hydrophone arrays and to trace the oceanic migration using the data recovered from the DSTs. The second experiment was designed to enable further assessment of the oceanic migrations, and so approximately half of the eels from each river were tagged with satellite tags and half were tagged with e-DSTs to increase data recovery. The number and type of tags at the different release sites by year are shown in Table 1. Tagged eels were released from the shore after sundown.

The data from the PSATs were transmitted to the Argos system and decoded by Microwave Telemetry. Recovery of data from e- and i-DSTs depended on retrieval of tags that drifted to the shore. Tags were recovered from the shorelines of western Scotland and as far as northern Norway, and a reward was paid to the finder.

\section{Acoustic tracking}

The Gullmaren fjord is approximately $25 \mathrm{~km}$ long and 1 to $3 \mathrm{~km}$ wide, with a U-shaped cross-section and 100 to $120 \mathrm{~m}$ maximum depth, except at the threshold to the Skagerrak, where the threshold depth is 20 to $40 \mathrm{~m}$. Five Vemco VR2W or VR2 receivers were deployed at 3 transects downstream of the release location (Fig. 1). The receivers were anchored with a subsurface buoy approximately $1 \mathrm{~m}$ above the seabed and, for retrieval, with a $60 \mathrm{~m}$ rope stretched along the bottom to a second anchor. The depth of the receiver varied from 10 to $40 \mathrm{~m}$ in different localities. The innermost single receiver was placed $5 \mathrm{~km}$ from the release point, where the distance to the opposite shore was $0.35 \mathrm{~km}$, deemed enough to cover the section by 1 hydrophone (Transect 1). At the next 2 sections (Transects 2 and 3), 2 receivers, one on each side of the fjord, were moored 1.3 and $1.2 \mathrm{~km}$ apart, respectively. The number of receivers available did not allow for a closer spacing. A range test made at transect 3 with a control tag gave a minimum range of $250 \mathrm{~m}$ with $100 \%$ detection probability. The maximum range varied greatly with direction and depth from the receiver because of the strong stratification and complicated bathymetry in this area. As a result, the acoustic reception of each transect did not completely cross the fjord, allowing some potential passages to go undetected (DG Pincock unpubl. data, www.vemco.com/pdf/line_ performance.pdf, accessed 5 Jan 2014). All receivers were deployed $2 \mathrm{wk}$ before eels were released, and all were successfully retrieved on 13 or 14 December 2010 .

\section{Analysing oceanic migrations}

The trajectories of PSAT- and e-DST-tagged eels were reconstructed by first estimating the longitude at an interval of approximately $7 \mathrm{~d}$ or every 100 to $150 \mathrm{~km}$. Longitude was calculated by using the diurnal swimming depth changes of the eel as a proxy for sunset and sunrise; this provides an estimate of the time of local noon and thereby the longitude (Nielsen et al. 2006). All the eels displayed this diurnal cycle, and there is strong justification to believe that the depth changes are cued to dawn and dusk (Westerberg et al. 2007). Fig. 2 gives an example of the diurnal depth change for 2 PSATs during the days preceding their pop-up. Linear regression of the longitude estimates for the dates preceding pop-up with the longitude of the transmitted first position provided validation of this technique (transmitted longitude $=1.015 \times$ calculated longitude, $\left.F_{1,7}=195, \mathrm{p}<0.001\right)$. However,

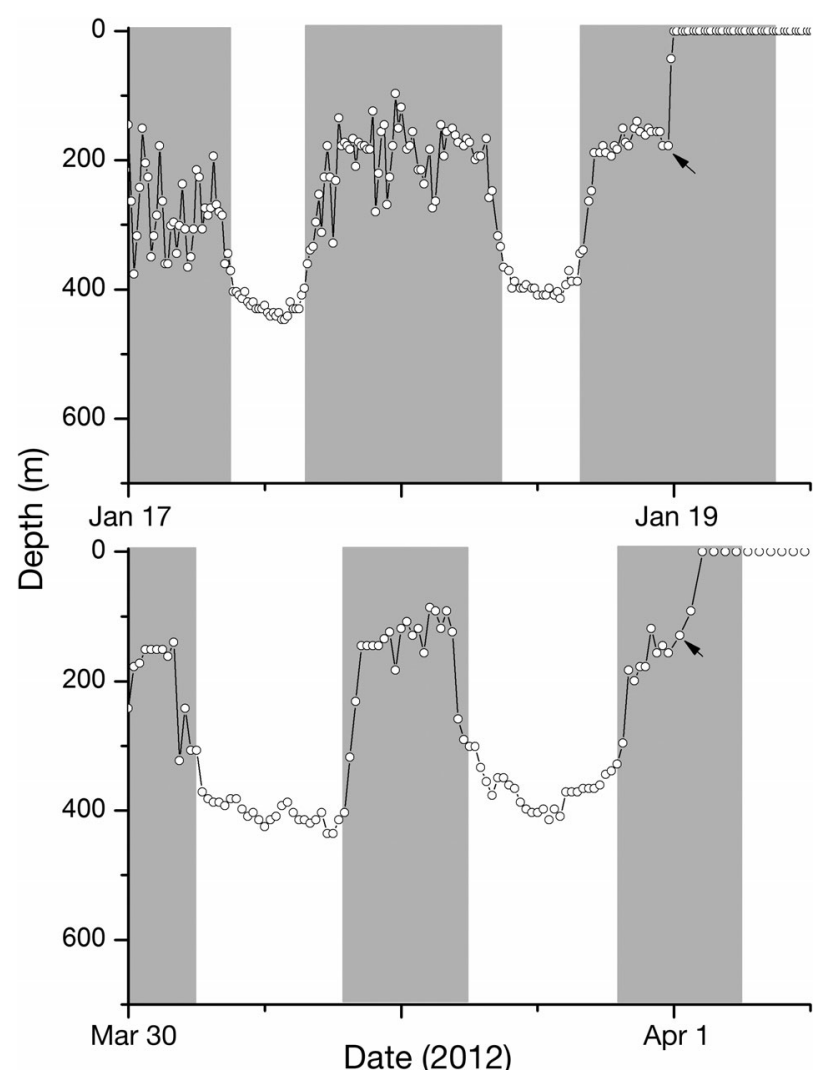

Fig. 2. Examples of the diurnal diving activity preceding the surfacing of 2 pop-up satellite tags. Shaded areas show the time between sunset and sunrise at the first Argos location of the tag. Upper panel tag 111817, surfacing 19 January 2012 (indicated by arrow), latitude $61.28^{\circ} \mathrm{N}$ and longitude $1.9^{\circ} \mathrm{W}$. Lower panel tag 111809, surfacing 1 April 2012, latitude $60.13^{\circ} \mathrm{N}$ and longitude $6.21^{\circ} \mathrm{W}$ 
because of variation in vertical migration behaviour from day to day and between eels, some longitude estimates were obvious outliers. To minimize this effect, we used estimates of longitude only for those periods when the timing of vertical migration behaviour showed low variability from day to day.

The time series of longitude estimates were then used as a starting point for further reconstruction of the trajectories of the eels. In the first step, position estimates were refined by comparing eel maximum daily depths with the bathymetry of the general area. This was particularly effective in the narrow Norwegian Trench south and west of Norway.

In a final refinement, we used specific hydrographic features that could be identified in most records and that were used as checkpoints. One point is where the swimming depth exceeded $450 \mathrm{~m}$ simultaneously with a longitude estimate less than $6^{\circ} \mathrm{E}$, which means that the eel must have reached the open Norwegian Sea at approximately $62^{\circ} \mathrm{N}$, since the maximum depth in the Norwegian Trench is less than $350 \mathrm{~m}$ along the west coast of Norway. Another unique point is where there was a sudden change in environmental temperature from less than $2^{\circ} \mathrm{C}$ to more than $7^{\circ} \mathrm{C}$ at depths greater than approximately $500 \mathrm{~m}$, clearly indicating when the eel passes the IcelandScotland ridge, separating the cold Norwegian Sea deep water from the warmer Atlantic water south of the ridge.

Three milestones were defined in the marine migration. The first was the release date. The second was the beginning of active oceanic migration, defined as the day when the maximum depth reached by the eel exceeded $100 \mathrm{~m}$, which corresponds to the entrance to the Norwegian Trench in the Skagerrak (see Fig. 1). The third milestone was the end position of the track, taken as the position of first transmission of a PSAT or the pop-up position of the DST. The former has a least-squares position error of less than $1.5 \mathrm{~km}$, while the latter was found by comparing the temperature recorded by the DST with satellite measurements of sea surface temperature (SST) for the current date. This provided a relatively narrow latitude estimate which was combined with the estimate of longitude at the end of the track. The position error depends mostly on the uncertainty of the longitude estimate and is on the order of $100 \mathrm{~km}$. To test for effects of longitude, origin and moon phase on habitat selection (either mean depth during the day or night or the difference between them), we used a generalised linear mixed model analysis using the glmm function of the nlme library (Pinheiro et al. 2012) within R 2.14.2 (R Development Core Team
2012). Year, day of the year and eel ID were included in the model as random factors. The relationship between temperature experience (mean temperature during the day or night) was explored in the same way.

\section{RESULTS}

\section{Fjord behaviour}

All but one of the eels tagged with acoustic transmitters were detected after release by at least one of the receivers at one transect (total detections 2128, median 38 detections per eel). Several tags were undetected at Transect 1 or 2 but were recorded at Transect 3 near the fjord threshold (Table S4 in the Supplement). The most likely reason that eels were not detected was that the eel was too far from the receiver for the tag signal to be successfully detected. More detections were made during the time of the new moon than during the full moon (Fig. 3), although this difference was not statistically significant. Not all of the tags were detected at the final transect; the number of individuals detected at the end of the fjord decreased to 17 from 25 at the 2 inner transects. The total period of time that the eels stayed in the fjord varied. The first eel to leave the fjord was registered at the exit of the fjord after $7 \mathrm{~d}$, while the last to leave was recorded at the outer transect after $52 \mathrm{~d}$.

We used the differences in time between the last recording of a tag at each transect to determine the transit time of individual eels in each group (Table 2).

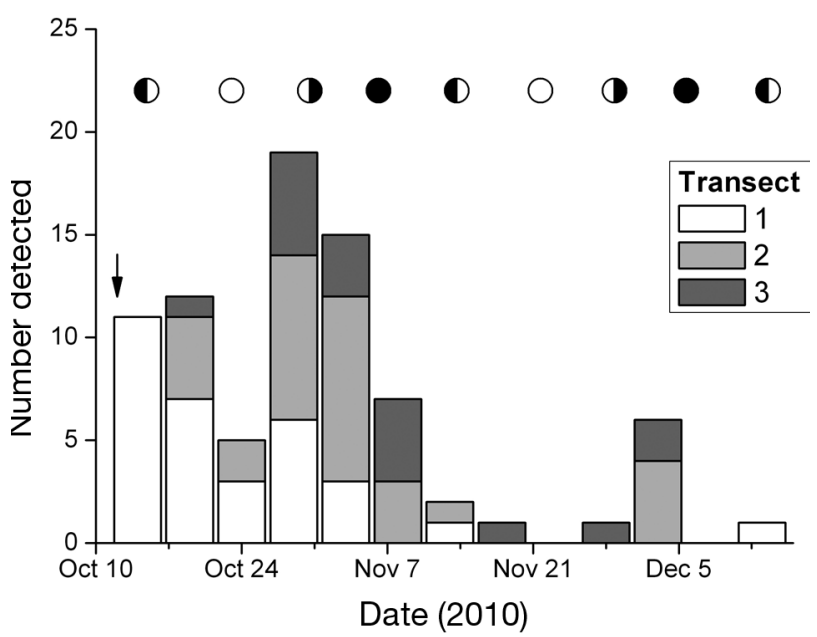

Fig. 3. Number of individual eels registered per $5 \mathrm{~d}$ period at the different transects. Symbols show the phases of the moon (arrow indicates the release date). Transect numbers as in Fig. 1 
Table 2. Mean \pm SD and number of observations (n) of the transit time in days between the release point and the last record of the acoustic tag at Transect 1 (T1) and between different pairs of transects. A Kolmogorov-Smirnov test showed no significant deviation from normality for the data in each transect interval and river group $(0.17<\mathrm{p}<0.95)$; hence, a heterogeneous $t$-test of the difference between the mean transit time of the River Enningdal and Ätran groups has been calculated for each inter-transect comparison

\begin{tabular}{|c|c|c|c|c|c|c|c|c|c|}
\hline \multirow{2}{*}{ Interval } & \multicolumn{3}{|c|}{ —Enningdal —— } & \multicolumn{3}{|c|}{ - Ätran } & \multicolumn{3}{|c|}{$t$-test } \\
\hline & Mean & $\mathrm{SD}$ & $\mathrm{n}$ & Mean & $\mathrm{SD}$ & $\mathrm{n}$ & $t$ & $\mathrm{df}$ & $\mathrm{p}$ \\
\hline Release to T1 & 12.67 & 9.18 & 12 & 12.86 & 15.9 & 13 & -0.04 & 19.5 & 0.97 \\
\hline T1 to T2 & 6.39 & 8.02 & 10 & 12.12 & 17.84 & 11 & -0.96 & 14.3 & 0.35 \\
\hline $\mathrm{T} 2$ to $\mathrm{T} 3$ & 9.75 & 14.44 & 9 & 4.3 & 5.26 & 7 & 1.05 & 10.55 & 0.32 \\
\hline $\mathrm{T} 1$ to $\mathrm{T} 3$ & 15.26 & 13.31 & 9 & 14.58 & 16.81 & 5 & 0.08 & 6.85 & 0.94 \\
\hline
\end{tabular}

time. For example, 4 eels (3 from Enningdal and 1 from Ätran) completed the migration between the inner and outer transects in less than $2 \mathrm{~d}$, indicating more or less continuous swimming. Conversely, 3 eels took more than $40 \mathrm{~d}$, which likely indicates periods of rest between bouts of active migration. In 6 cases, the eels covered the distance between the first and middle transect or from the middle to the second transect in the same night (Tables S4 \& S5 in the Supplement). If we assume that this represents continuous swimming on a relatively

The time from release to the first transect was similar between eels of different origin, at approximately 13 d. Eels from the River Ätran took, on average, $12 \mathrm{~d}$ to pass from Transect 1 to Transect 2, almost double that of the Enningdal eels (6.4 d). However, this difference was reversed in the remaining portion of the journey, where Ätran eels took only $4.3 \mathrm{~d}$ between transects in comparison to $9.75 \mathrm{~d}$ for the Enningdal eels. None of these transit times were significantly different.

From the innermost acoustic line, the mean swimming velocity of each eel can be calculated over the 11 and $7.5 \mathrm{~km}$ intervals between successive transects. The individual values varied between 0.2 and $42 \mathrm{~km} \mathrm{~d}^{-1}$ and will have done so partly because of real differences in swimming velocity, straightness of trajectory or periods of rest at the bottom during day- straight course along the fjord, the mean swimming velocity over ground can be calculated. The speed of those eels varied between 30 and $42 \mathrm{~km} \mathrm{~d}^{-1}$ or 0.34 to $0.53 \mathrm{BL} \mathrm{s}^{-1}$; however, sample size was insufficient to make a comparison between the groups.

\section{Oceanic migration}

Of the 99 eels tagged with DSTs or PSATs, data were recovered from 24 tags. Three PSATs and 3 eDSTs surfaced after less than $7 \mathrm{~d}$ and provided no useful data on migration. The reason for the premature release of these tags is unclear and could have been because of entanglement in fishing gear or eels being preyed on by seals or other predators. One eDST had a malfunctioning pressure sensor and gave

Table 3. Tag type (PSAT = externally attached pop-up satellite tag, i-DST = implanted data storage tag, e-DST = externally attached data storage tag), origin, release and surfacing dates (given as dd/mm/yy), position and distance to the end of track and type of ending ( $\mathrm{a}=$ programmed release, $\mathrm{b}=$ possible predation, $\mathrm{c}=$ tag malfunction) for the 17 long tracks used in the analysis. Negative longitudes are west of Greenwich

\begin{tabular}{|c|c|c|c|c|c|c|c|c|c|c|}
\hline Tag no. & Type & $\begin{array}{l}\text { Capture } \\
\text { site }\end{array}$ & $\begin{array}{l}\text { Release } \\
\text { site }\end{array}$ & $\begin{array}{l}\text { Release } \\
\text { date }\end{array}$ & $\begin{array}{l}\text { Pop-up } \\
\text { date }\end{array}$ & $\begin{array}{l}\text { Latitude } \\
\qquad\left({ }^{\circ} \mathrm{N}\right)\end{array}$ & Longitude & Days & $\begin{array}{l}\text { Distance } \\
(\mathrm{km})\end{array}$ & Ending \\
\hline 111804 & PSAT & Ätran & Marstrand & $27 / 10 / 11$ & $02 / 02 / 12$ & 62.4 & -0.4 & 98 & 1434 & a \\
\hline 111809 & PSAT & Ätran & Marstrand & $27 / 10 / 11$ & 01/04/12 & 60.1 & -6.2 & 157 & 2130 & $\mathrm{a}$ \\
\hline 111812 & PSAT & Ätran & Marstrand & $27 / 10 / 11$ & $01 / 04 / 12$ & 57.6 & -9.8 & 157 & 1748 & $\mathrm{a}$ \\
\hline 111813 & PSAT & Ätran & Marstrand & $27 / 10 / 11$ & $01 / 04 / 12$ & 55 & -13.4 & 157 & 2177 & $\mathrm{a}$ \\
\hline 111814 & PSAT & Ätran & Marstrand & $27 / 10 / 11$ & 01/04/12 & 58.4 & -11.7 & 157 & 1995 & $\mathrm{a}$ \\
\hline 111815 & PSAT & Enningdal & Marstrand & $28 / 10 / 11$ & $01 / 04 / 12$ & 62.2 & -0.3 & 156 & 2073 & $\mathrm{a}$ \\
\hline 111816 & PSAT & Enningdal & Marstrand & $29 / 10 / 11$ & $01 / 04 / 12$ & 58.7 & -10.7 & 156 & 2321 & $\mathrm{a}$ \\
\hline 111817 & PSAT & Enningdal & Gullmaren & $30 / 10 / 11$ & 18/01/12 & 60.2 & -3.3 & 83 & 1667 & b \\
\hline A06840 & i-DST & Enningdal & Gullmaren & $12 / 10 / 10$ & $29 / 12 / 10$ & 58.5 & 5 & 78 & 565 & $\mathrm{~b}$ \\
\hline A06869 & e-DST & Enningdal & Gullmaren & $12 / 10 / 10$ & $05 / 12 / 10$ & 60.4 & -4.5 & 54 & 1204 & $\mathrm{a}$ \\
\hline A06874 & e-DST & Enningdal & Gullmaren & $13 / 10 / 10$ & $10 / 12 / 10$ & 61.7 & -1 & 58 & 1192 & $\mathrm{a}$ \\
\hline A06878 & e-DST & Ätran & Marstrand & $13 / 10 / 10$ & $10 / 12 / 10$ & 60 & -5.5 & 58 & 1218 & $\mathrm{a}$ \\
\hline A07217 & e-DST & Ätran & Marstrand & $28 / 10 / 11$ & $15 / 12 / 12$ & 65.4 & 10.3 & 79 & 1704 & $\mathrm{a}$ \\
\hline A07224 & e-DST & Enningdal & Marstrand & $27 / 10 / 11$ & $24 / 12 / 11$ & 58.2 & 8.4 & 58 & 493 & $\mathrm{~b}$ \\
\hline A07234 & e-DST & Ätran & Marstrand & $27 / 10 / 11$ & $15 / 03 / 12$ & 58.6 & -9.8 & 140 & 2329 & $\mathrm{a}$ \\
\hline A07235 & e-DST & Ätran & Marstrand & $27 / 10 / 11$ & $22 / 01 / 12$ & 57.5 & 4 & 87 & 580 & $\mathrm{C}$ \\
\hline A07237 & e-DST & Ätran & Marstrand & $27 / 10 / 11$ & $15 / 03 / 12$ & 54.6 & -10 & 140 & 1020 & $\mathrm{a}$ \\
\hline
\end{tabular}


no usable data. The salient results for the comparison between stocked and naturally recruited eels are the remaining 17 tracks with durations between 1.5 and 5 mo (Table 3). There was no significant difference in eel length, weight or silvering index between the eels that carried tags that were recovered and those that did not (heterogeneous $t$-tests, $p>0.05$ in all cases, Table S2 in the Supplement), and hence the tags recovered from Ätran eels were from slightly smaller eels than those originating from Enningdal eels (Table S2). Of the returned tags, 11 were attached to eels that originated from the River Ätran (6 e-DSTs and 5 PSATs), and 6 were from the River Enningdal (2 e-DSTs, 1 i-DST and 3 PSATs). These tags yielded, in total, $1227 \mathrm{~d}$ of data for eels caught in the River Ätran and $606 \mathrm{~d}$ for eels caught in the River Enningdal.

The reconstructed trajectories for those 17 eels are shown in Fig. 4. All eels followed essentially the same route through the Skagerrak and along the Norwegian west coast. The main guide for the eels appeared to be the Norwegian Trench, where the depth is greater than $200 \mathrm{~m}$ and up to $700 \mathrm{~m}$ in the Skagerrak south of Norway. In the Norwegian Sea, the trajectories became more dispersed, but except for one Enningdal eel that migrated to the northeast, the overall result was that the eels turned southwest and followed the continental shelf, past the Iceland-Scotland ridge into the Rockall Channel west of Scotland.

The reconstructed trajectories were used to calculate the average migration speed. In the first stage of the migration, from the coast to the start of active oceanic migration (depth $>100 \mathrm{~m}$ ), there was often a period where the eels spent time at the seabed in shallow water. This varied between 1 and $32 \mathrm{~d}$ for the Ätran eels, mean $12 \mathrm{~d}$ (Table 4), and 7 to $38 \mathrm{~d}$ for the Enningdal eels, mean 25 d (heterogeneous 2-sample $t$-test, $\left.t_{9}=2.5, \mathrm{p}<0.05\right)$. In the second stage, from the start of the oceanic migration to the time when the tag was released from the eel, the mean $( \pm$ SD) migration speed was $21.6 \mathrm{~km} \mathrm{~d}^{-1}\left( \pm 8.1 \mathrm{~km} \mathrm{~d}^{-1}\right.$, range 12.2 to $51 \mathrm{~km} \mathrm{~d}^{-1}$ ), with no significant difference in

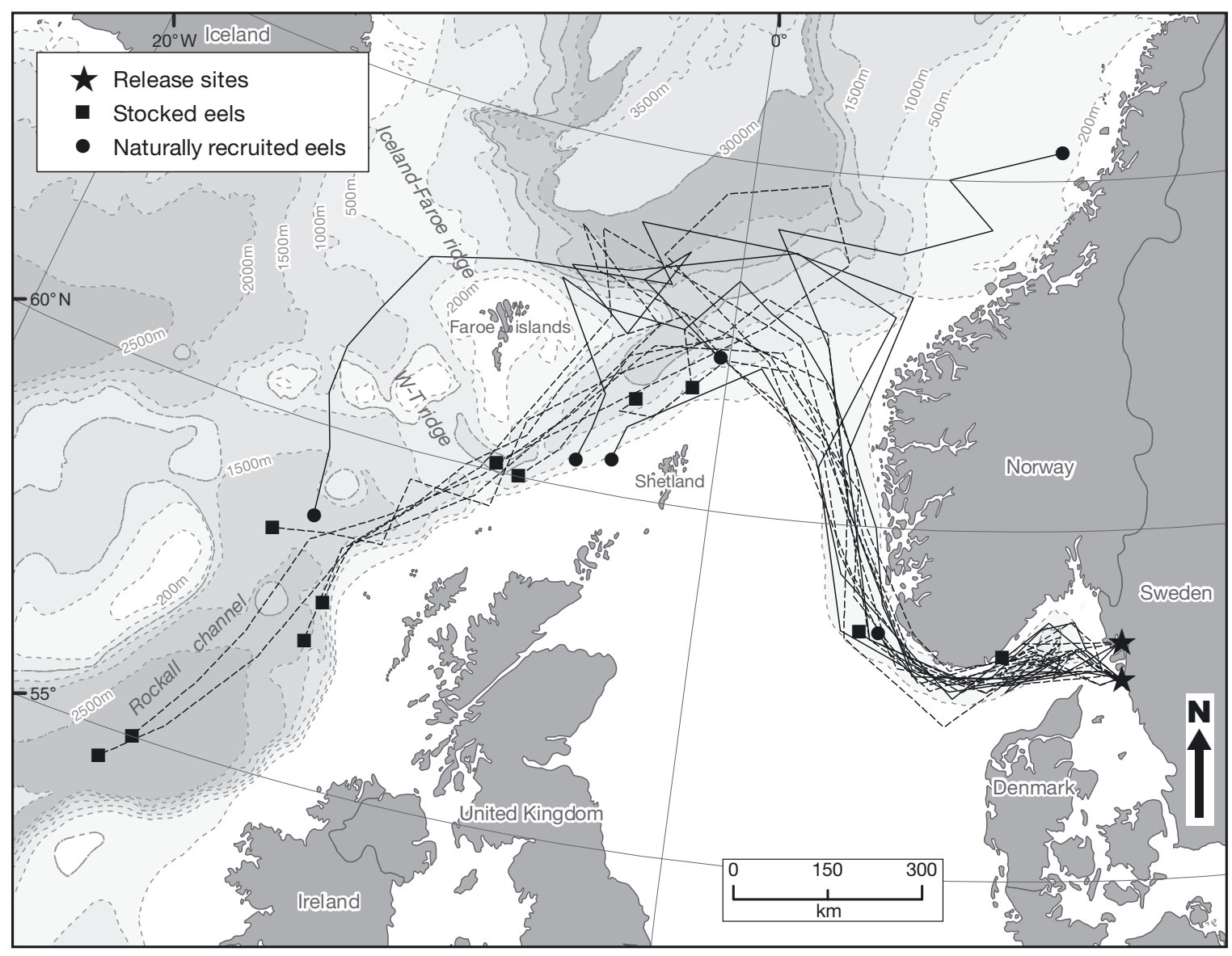

Fig. 4. Trajectories of eels from the rivers Ätran (dashed lines) and Enningdal (solid lines). The Iceland-Faroe and WyvilleThompson (W-T) ridges are the 2 parts of the Scotland-Iceland ridge 
Table 4. Summary of ocean migration behaviour of naturally recruited (Enningdal) eels $(\mathrm{n}=6)$ and stocked (Ätran) eels $(\mathrm{n}=11$, except as noted) calculated from the point where the maximum swimming depth exceeded $100 \mathrm{~m}$ in the Skagerrak (i.e. Skagerrak entrance, row 1). Values for speed and duration of migration are calculated as average \pm SD values for individuals, while values for depth and temperature are calculated at each estimated location for eels in the 2 experimental groups. ns: not significant at the $5 \%$ level

\begin{tabular}{|c|c|c|c|c|c|}
\hline Parameter & Enningdal & Ätran & $t$ & df & $\mathrm{p}$ \\
\hline Time to Skagerrak entrance (d) & $25.33 \pm 10.54$ & $12.45 \pm 9.05$ & 2.6 & 9.1 & 0.03 \\
\hline Speed to Norwegian Sea $\left(\mathrm{km} \mathrm{d}^{-1}\right)$ & $26.28 \pm 5.40$ & $25.64 \pm 14.08(\mathrm{n}=8)$ & 0.11 & 9.95 & ns \\
\hline $\mathrm{BL} \mathrm{s}^{-1}$ to Norwegian Sea & $0.31 \pm 0.08$ & $0.33 \pm 0.19$ & 0.3 & 9.6 & ns \\
\hline Speed to end of track $\left(\mathrm{km} \mathrm{d}^{-1}\right)$ & $26.52 \pm 8.53$ & $18.89 \pm 6.80$ & 1.8 & 8.6 & ns \\
\hline $\mathrm{BL} \mathrm{s}^{-1}$ to end of track & $0.32 \pm 0.11$ & $0.25 \pm 0.09$ & 1.3 & 8.7 & ns \\
\hline Daytime depth (m) & $285.9 \pm 95.83$ & $281.549 \pm 108.1$ & 0.23 & 72 & ns \\
\hline Nighttime depth (m) & $109.9 \pm 72.6$ & $127.8 \pm 76.2$ & 1.3 & 67.2 & ns \\
\hline Daytime temperature $\left({ }^{\circ} \mathrm{C}\right)$ & $6.66 \pm 2.44$ & $6.97 \pm 1.86$ & 0.7 & 50.7 & ns \\
\hline Nighttime temperature $\left({ }^{\circ} \mathrm{C}\right)$ & $8.82 \pm 1.33$ & $9.12 \pm 0.06$ & 1.2 & 52 & ns \\
\hline
\end{tabular}

the migration speed of stocked or naturally recruited eels $\left(t\right.$-test, $t_{8.6}=1.9, \mathrm{p}>0.05$, Table 4$)$ or in BL $\mathrm{s}^{-1}\left(t\right.$-test, $t_{8.7}=1.4, \mathrm{p}>0.05$, Table 4$)$. However, because the total length of the trajectories varied considerably, it is more appropriate to make comparisons between the groups over a standardised distance. Most tracks $(\mathrm{n}=14)$ covered the approximately $900 \mathrm{~km}$ distance between the $100 \mathrm{~m}$ contour in the Skagerrak and the entry to the Norwegian Sea, with an average speed of $25.9 \mathrm{~km} \mathrm{~d}^{-1}\left( \pm 10.9 \mathrm{~km} \mathrm{~d}^{-1}\right)$. Again, there was no difference in swimming speed between stocked or naturally recruited eels ( $t$-test, $t_{8.6}=1.9, \mathrm{p}>0.05$, Table 4$)$ or in BL s${ }^{-1}\left(t\right.$-test, $t_{9.6}=0.3$, $\mathrm{p}>0.05)$.

During migration, all the eels showed a continuous diurnal depth cycle, with a deeper swimming level during the daylight period $(282.7 \pm 104.6 \mathrm{~m})$ and shallower swimming level during the night $(123 \pm$ $75.4 \mathrm{~m}$ ). The shift between deep and shallow residence depths was essentially synchronous between eels in the same area and likely cued by the daylight variation. Fig. 5 gives an example of the simultaneous depth records of 1 eel from each group, both of which were located in the Norwegian Sea approximately 3 mo after release. The diurnal behaviour of

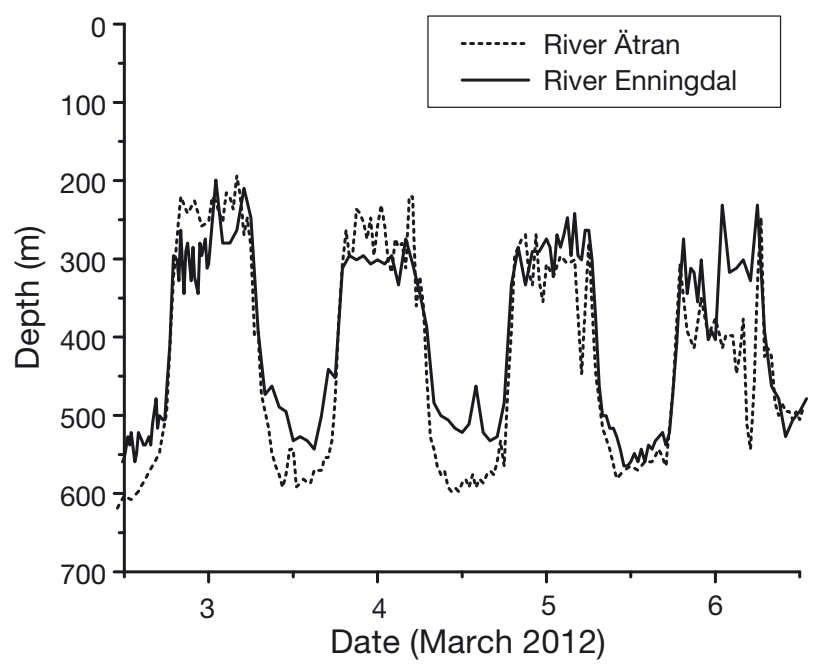

Fig. 5. Simultaneous record of swimming depth of 2 eels in approximately the same area of the Norwegian Sea, one (\#111814) of stocked origin from the River Ätran and the other (\#111816) of naturally recruited origin from the River Enningdal

the stocked and naturally recruited groups was assessed using a linear mixed model. Longitude proved to be a highly significant $(p<0.01$, Table 5$)$ predictor of daytime vertical position and vertical range; as

Table 5. Effect of environment (longitude and moon phase) and origin on the habitat selection of eels during their oceanic migration. Values in the table provide the significance (probability of effect, p) of each factor in a generalized linear mixed model, with interactions between different factors. Year, day of year and eel ID were included in the model as random factors

\begin{tabular}{|lcccccc|}
\hline & Longitude & $\begin{array}{c}\text { Moon } \\
\text { phase }\end{array}$ & Origin & $\begin{array}{c}\text { Longitude } \\
\times \text { origin }\end{array}$ & $\begin{array}{c}\text { Moon phase } \\
\times \text { origin }\end{array}$ & $\begin{array}{c}\text { Longitude } \times \text { moon } \\
\times \text { origin }\end{array}$ \\
\hline Mean depth $(\mathrm{m})$ during day & $<0.05$ & 0.80 & 0.27 & 0.69 & 0.72 & 0.89 \\
Mean depth $(\mathrm{m})$ during night & 0.63 & 0.58 & 0.31 & 0.61 & 0.72 & 0.82 \\
Depth range $(\mathrm{m})$ & $<0.05$ & 0.68 & 0.90 & 0.35 & 0.98 & 0.81 \\
Mean temperature $\left({ }^{\circ} \mathrm{C}\right)$ during day & 0.84 & 0.89 & 0.44 & 0.22 & 0.80 & 0.63 \\
Mean temperature $\left({ }^{\circ} \mathrm{C}\right)$ during night & 0.69 & 0.45 & 0.10 & 0.09 & 0.39 & 0.32 \\
\hline
\end{tabular}


eels travelled towards the Sargasso Sea, they occupied deeper water during the day and therefore moved over a larger depth range (linear regression: day depth $=-16.4 \times$ longitude $+358.4, F_{1,135}=224.7$, $\mathrm{p}<0.01$ and depth range $=-8.17 \times$ longitude +197.4 , $\left.F_{1,135}=74, \mathrm{p}<0.01\right)$. Eel origin, moon phase or the interaction between eel origin and longitude, or any of the random effects in the model (year of tagging, day of year or eel ID), were not significant in any of the models ( $p>0.05$, Table 5). Surprisingly, longitude was not a significant predictor of temperature experience (Table 5).

\section{DISCUSSION}

We used several different methods of telemetry to determine the movements and migrations of European eels of different origin. The results from our analysis of the initial behaviour in the fjord, at-sea migration and vertical movements do not suggest that the navigation of naturally recruited eels versus those of probable stocked origin is significantly different. Our experiments were conducted in separate years, and while there were some small differences in BL and weight between the experimental groups overall (but not within each year), the migration speed, timing of migration and migration route taken as well as vertical behaviour were not different between experimental groups.

\section{Migration speeds}

During the initial period after release in the fjord, there were no statistically significant differences in delay before arrival at the first acoustic transect or in average time to departure from the fjord between the stocked eels from the River Ätran and the naturally recruited eels from the River Enningdal. Unfortunately, we were not able to set up the acoustic array in the fjord to enable $100 \%$ detection of tags as they passed down the fjord, so not all eels were detected at each acoustic transect, and we were not able to confirm the departure of all eels from both experimental groups. However, the experimental setup in the fjord is similar to that used by Aarestrup et al. $(2008,2010)$ to study down-river migration of eels in the Randers fjord in Denmark and by Davidsen et al. (2011) in the Alta fjord in northern Norway. Just as for our results, these studies showed that there was a low average speed and large spread of out-migration delay but with some eels finding their way to the sea very rapidly. The maximum continuous speed we recorded over a single night ( $42 \mathrm{~km} \mathrm{~d}^{-1}$, Table S5) was similar to the maximum speed found in previous eel tagging experiments in the Baltic (Sjöberg \& Petersson 2005).

Stocked eels navigated from the coast to the onset of oceanic migration at the entrance to the Skagerrak more quickly than naturally recruited eels. However, in the subsequent offshore migration during several months and, for some eels, over a distance of more than $2000 \mathrm{~km}$, the swimming speed (expressed either as speed over ground or in BL s${ }^{-1}$ ) of both stocked and naturally recruited eels was not significantly different. Both groups achieved an average speed over ground of approximately $25 \mathrm{~km} \mathrm{~d}^{-1}$ (corresponding to $\sim 0.3 \mathrm{BL} \mathrm{s}^{-1}$ ), with this average reaching up to $51 \mathrm{~km}$ $\mathrm{d}^{-1}$ over the section between the Skagerrak and the Norwegian Sea in one case. The average speed is greater than that reported in previous studies of oceanic eel migration (Aarestrup et al. 2009) and may reflect the greater spatial accuracy with which we reconstructed the migration route. These data also suggest that the swimming ability of eels was not significantly compromised by the tag or the tagging procedure (Methling et al. 2011) and, as suggested in previous studies, provides optimism that tracking the full journey to the Sargasso Sea will be possible with further improvements in tag technology.

\section{Migration route}

Eels from both experimental groups took the same route along the Norwegian Trench into the Norwegian Sea before turning southwest somewhere north of $62^{\circ} \mathrm{N}$ once they reached the Norwegian Sea. A single eel from the River Enningdal continued north in the Norwegian Sea until the tag popped off. However, several other eels meandered in the Norwegian Sea before turning south and west towards the Atlantic. All eels showed a daily maximum depth which excludes any alternative, shorter route across the North Sea or south of the Shetland Islands. This 'Nordic' migration route resolves many decades of speculation about the route that eels take once they leave the Baltic (Westerberg 2013) and is corroborated by observations of by-catch of silver eels in bottom trawl surveys in the North Sea and the Baltic during groundfish and shrimp surveys in the autumn (e.g. Norwegian Pandalus Survey, North Sea International Bottom Trawl Survey and Baltic International Trawl Survey). These results suggest that eels, whether stocked or naturally recruited, are not 
dependent on an imprinted route, at least for the section of the route east of where the eel reaches the continental shelf. Which navigational cues are used is unknown, but orientation seems to be mapindependent.

To describe the geographic migrations of tagged eels, it was necessary for us to develop a technique of geolocation based on eel behaviour and the primary hydrographic signals that the tag datasets provided because no other existing geolocation technique, e.g. light-based or SST-based (Nielsen et al. 2006), was suitable. Although our geolocation technique allowed us to reconstruct the migrations of eels in unprecedented detail, the reconstruction of the migrations is in some ways coarse and lacks finer details. For example, there are probably several unrecorded meanderings, especially in the Norwegian Sea and in the deep part of the Norwegian Trench south of Norway. Further development of our technique, using state-space models (Patterson et al. 2008) or more complex water column profile matching techniques, will enable these finer-scale details to be resolved.

\section{Vertical movements and activity}

The behaviour of the eels varied over the course of the lunar and diel cycles and over the period of their oceanic migration. In the fjord, the activity of the eels varied with the lunar phase, with a peak in activity around the fourth quarter of the moon (Fig. 3). The effect of the lunar cycle on silver eels as they move downstream to the sea during autumn is well known both from laboratory studies and in the fishery (e.g. Boëtius 1967 and Lindroth 1979). No effect of the moon was found in the behaviour of the eels once they left the fjord, however.

During the ocean phase of migration, eels showed a large-amplitude diurnal change in swimming depth that has been described in previous studies of European eels (e.g. Tesch 1978, Aarestrup et al. 2009) as well as, more recently, other Anguilla species (Jellyman \& Tsukamoto 2010, Béguer-Pon et al. 2012, Schabetsberger et al. 2013). There was no significant difference in the depths that eels occupied during the day or night, or in the depth range, between stocked or naturally recruited eels, i.e. the diel behaviour did not differ between groups. The large dusk ascent and large dawn descent were clearly cued to changes in light level between day and night, which supports a hypothesis of predator avoidance during the day (Schabetsberger et al. 2013). Furthermore, daytime swimming depth and depth range were significantly influenced by longitude, suggesting that there are environmental factors that influence these aspects of eel habitat occupation that are associated with the westward migration. However, since the occupied temperatures of eels of stocked or natural origin were not influenced by longitude, this remains an open question.

\section{Effect of eel origin on migration}

We could not be sure that the individuals that we tagged were definitely of stocked or natural origin since the only current method to achieve this is by otolith microchemistry, which requires sacrifice of the eel. The results of our otolith reference assessment confirmed that $100 \%$ of eels caught in the Enningdal at the same time and in the same place as our first tagged group were natural recruits and that $80 \%$ of the eels caught in the Ätran were stocked as glass eels. However, the number of tags recovered from presumed stocked and presumed natural recruits was only a small proportion of those tagged (25\%) and, in principle, the recovered sample could be highly skewed, such that all tags recovered from River Ätran eels were eels originally stocked from the Swedish coast. However, $70 \%$ of the PSATs attached to presumed stocked eels were recovered and returned long tracks, which means that at least some (and probably the majority) of these must have been stocked as translocated glass eels.

Despite this slight uncertainty, and although there were small differences in the overall average BL and weight between stocked and naturally recruited groups, we believe that the strength of this study is that there is a comparison between groups with a well-known immigration history. The only other study fulfilling this is the tagging studies with Carlin or Floy tags conducted by Westin in the Baltic (Westin 1998, 2003). Based on a larger spread of tag recaptures and a high degree of overwintering in stocked eels, he concluded that there was a clear behaviour difference in the ability to orientate and that this was caused by a lack of imprinted learning of the route in stocked eels. In the context of our results, we found no difference in behaviour between naturally recruited and stocked eels, which does not support the hypothesis that a sequential imprinting of the route during the immigration is necessary for adequate orientation during the spawning migration. The argument that stocked glass eels are unable to navigate is not supported, therefore, at least outside the Baltic basin. It remains to be investigated if there 
is a special requirement of early imprinting to negotiate the navigation difficulties of finding the Baltic outlet or if the results reported by Westin simply reflect a requirement for a period of feeding in the marine environment to increase fat content before the marine migration (Svedäng \& Wickström 1997, Limburg et al. 2003).

\section{Further work and implications for management}

Our results provide, in considerable detail, the longest distances that any eel has been tracked and account for approximately one-third of the total distance from the Skagerrak to the Sargasso Sea. However, our results do not prove that translocated glass eels contribute to the spawning population because none of the tracked eels, stocked or naturally recruited, could be followed to reach the Sargasso Sea and, furthermore, the relatively low sample size did not enable us to assess relative survival rates of stocked versus naturally recruited eels. Nonetheless, the results obtained from the tagging methods used here are encouraging. Smaller DSTs and satellite tags are becoming available, and there should be a realistic chance to cover the whole spawning migration. This potentially allows comparison of the survival and migration success between both stocked and unstocked eels and eels coming from different parts of the distribution range.

In conclusion, the lack of any difference in migration behaviour, either from the fjord or at sea, in terms of migration route, swimming speeds or vertical migration is the strongest indication yet that stocked glass eels have navigational and behavioural abilities similar to those of naturally recruited eels. This provides evidence in support of stocking as a measure to recover the stock of European eels within the framework of the EU's EMPs. Evidently, there are also relevant concerns about the use of stocking as a management measure. In the present situation, with a dramatic decline of recruitment, stocking merely to compensate for fishery or other anthropogenic mortality is futile.

Acknowledgements. This review is part of a study funded by Grant Agreement GOCE-2008212133 (eeliad) of the EU FP7 research program on the environment (including climate change) and prepared under project number 212133. We are grateful to P. O. Wahrnberg, who supplied the eels from River Enningdal. F. Økland and several members of the eel research team from the University of Karlstad helped in the tagging operations. I. Alenäs provided valuable information about historic stockings in Lake Fegen.

\section{LITERATURE CITED}

Aarestrup K, Thorstad EB, Koed A, Jepsen N and others (2008) Survival and behaviour of European silver eels in late freshwater and early marine phase during spring migration. Fish Manag Ecol 15:435-440

- Aarestrup K, Økland F, Hansen MM, Righton D and others (2009) Oceanic spawning migration of the European eel (Anguilla anguilla). Science 325:1660

> Aarestrup K, Thorstad EB, Koed A, Svendsen JC, Jepsen N, Pedersen MI, Økland F (2010) Survival and progression rates of large European silver eel Anguilla anguilla in late freshwater and early marine phases. Aquat Biol 9: 263-270

> Als TD, Hansen MM, Maes GE, Castonguay M and others (2011) All roads lead to home: panmixia of European eel in the Sargasso Sea. Mol Ecol 20:1333-1346

- Béguer-Pon M, Benchetrit J, Castonguay M, Aarestrup K, Campana SE, Stokesbury MJW, Dodson JJ (2012) Shark predation on migrating adult American eels (Anguilla rostrata) in the Gulf of St. Lawrence. PLoS ONE 7:e46830

Boëtius J (1967) Experimental indication of lunar activity in European silver eels, Anguilla anguilla (L.). Medd Dan Fisk Havunders 6:1-6

$>$ Davidsen JG, Finstad B, Økland F, Thorstad EB, Mo TA, Rikardsen AH (2011) Early marine migration of European silver eel Anguilla anguilla in northern Norway. J Fish Biol 78:1390-1404

Dekker W (1998) Long-term trends in the glasseels immigrating at Den Oever, the Netherlands. Bull Fr Peche Piscic 349:199-214

Dekker W (2008) Coming to grips with the eel stock slipsliding away. In: Schlechter MG, Leonard NJ, Taylor WW (eds) International governance of fisheries ecosystems: learning from the past, finding solutions for the future. Am Fish Soc Symp 58:335-355

Dekker W (2012) Assessment of the eel stock in Sweden, spring 2012. First post-evaluation of the Swedish eel management plan. Aqua reports 2012:9. Swedish University of Agricultural Sciences, Drottningholm

> Durif C, Dufour S, Elie P (2005) The silvering process of Anguilla anguilla: a new classification from the yellow resident to the silver migrating stage. J Fish Biol 66: 1025-1043

EIFAC (European Inland Fisheries Advisory Commission) (1982) Documents presented at the symposium on stock enhancement in the management of freshwater fish. EIFAC Tech Pap No. 42, Suppl 1

Huertas M, Cerdà J (2006) Stocking density at early developmental stages affects growth and sex ratio in the European eel (Anguilla anguilla). Biol Bull 211:286-296

ICES (International Council for the Exploration of the Sea) (2011a) Report of the joint EIFAAC/ICES working group on eels (WGEEL), September 2011. ICES CM 2011/ACOM:18 www.ices.dk/sites/pub/Publication \%20 Reports/Expert\%20Group\%20Report/acom/2011/WGEEL /wgeel_2011.pdf (accessed 4 Jan 2014)

ICES (2011b) Advice November 2011. Widely distributed and migratory stocks: European eel. www.ices.dk/sites/ pub/Publication\%20Reports/Advice/2011/2011/eel-eur.pdf (accessed 4 Jan 2014)

Jellyman D, Tsukamoto K (2010) Vertical migrations may control maturation in migrating female Anguilla dieffenbachii. Mar Ecol Prog Ser 404:241-247

Limburg KE, Wickstrom H, Svedang H, Elfman M, Kristians- 
son P (2003) Do stocked freshwater eels migrate? Evidence from the Baltic suggests 'Yes'. Am Fish Soc Symp 33:275-284

Lindroth A (1979) Eel catch and lunar cycle on the Swedish east coast. Rapp P-V Réun Cons Int Explor Mer 174: 124-126

Malmqvist KG, Hylten G, Hult M, Hakansson K and others (1993) Dedicated accelerator and microprobe line. Nucl Instrum Methods Phys Res B 77:3-7

Methling C, Tudorache C, Skov PV, Steffensen JF (2011) Pop up satellite tags impair swimming performance and energetics of the European eel (Anguilla anguilla). PLoS ONE 6:e20797

Nielsen A, Bigelow KA, Musyl MK, Sibert JR (2006) Improving light-based geolocation by including sea surface temperature. Fish Oceanogr 15:314-325

Økland F, Thorstad EB, Westerberg H, Aarestrup K, Metcalfe JD (2013) Development and testing of attachment methods for pop-up satellite archival transmitters in European eel. Anim Biotelemetry 1:3

Pankhurst NW (1982) Relation of visual changes to the onset of sexual maturation in the European eel Anguilla anguilla (L.). J Fish Biol 21:127-140

Patterson TA, Thomas L, Wilcox C, Ovaskainen O, Matthiopolus J (2008) State-space models of individual animal movement. Trends Ecol Evol 23:87-94

Pinheiro J, Bates D, DebRoy S, Sarkar D, R Development Core Team (2012) nlme: linear and nonlinear mixed effects models. R package version 3.1-103

Prigge E, Marohn L, Hanel R (2013) Tracking the migratory success of stocked European eels Anguilla anguilla in the Baltic Sea. J Fish Biol 82:686-699

Pujolar JM, Maes GE, Volckaert FAM (2006) Genetic patchiness among recruits in the European eel Anguilla anguilla. Mar Ecol Prog Ser 307:209-217

R Development Core Team (2012). R: a language and environment for statistical computing. R Foundation for Statistical Computing, Vienna, Austria. www.R-project.org/

Rosell R, Evans D, Allen M (2005) The eel fishery in Lough Neagh, Northern Ireland - An example of sustainable management? Fish Manag Ecol 12:377-385

Schabetsberger R, Økland F, Aarestrup K, Kalfatak D and others (2013) Oceanic migration behaviour of tropical Pacific eels from Vanuatu. Mar Ecol Prog Ser 475: $177-190$

Submitted: March 13, 2013; Accepted: November 13, 2013
Sjöberg NB, Petersson E (2005) Blankålsmärkning - till hjälp för att förstå blankålens migration i Östersjön. Fiskeriverket informerar, FINFO 2005:3. www.havochvatten.se/ om-oss/publikationer/fiskeriverkets-publikationer/finfofiskeriverket-informerar/finfo/2012-01-27-finfo-20053blankalsmarkning.html (accessed 14 Jan 2014)

Svedäng H, Gipperth L (2012) Will regionalisation improve fisheries management in the EU? An analysis of the Swedish eel management plan reflects difficulties. Mar Policy 36:801-808

Svedäng H, Wickström H (1997) Low fat contents in female silver eels: indications of insufficient energetic stores for migration and gonadal development. J Fish Biol 50: 475-486

Svedäng $H$, Wickström $H$, Reizenstein M, Holmgren $K$, Florenius P (1998) Accuracy and precision in eel age estimation, using otoliths of known and unknown age. J Fish Biol 53:456-464

Tesch FW (1978) Telemetric observations on the spawning migration of the eel (Anguilla anguilla) west of the European continental shelf. Environ Biol Fishes 3:203-209

Thörne L, Carlsson M (2004) Fiskevårdsplan Fegen 2004. Länsstyrelsen i Jönköpings län. Meddelande 2004:45

Thorstad EB, Økland F, Westerberg H, Aarestrup K, Metcalfe JD (2013) Evaluation of surgical implantation of electronic tags in European eel and effects of different suture materials. Mar Freshw Res 64:324-331

Westerberg H (2013) Marine migratory behaviour of the European silver eel. In: Ueda $\mathrm{H}$, Tsukamoto $\mathrm{K}$ (eds). Physiology and ecology of fish migration. CRC Press, Boca Raton, FL, p 80-103

> Westerberg H, Lagenfelt I, Svedäng H (2007) Silver eel migration behaviour in the Baltic. ICES J Mar Sci 64: 1457-1462

> Westin L (1990) Orientation mechanisms in migrating European silver eel (Anguilla anguilla): temperature and olfaction. Mar Biol 106:175-179

> Westin L (1998) The spawning migration of European silver eel (Anguilla anguilla L.) with particular reference to stocked eel in the Baltic. Fish Res 38:257-270

> Westin L (2003) Migration failure in stocked eels Anguilla anguilla. Mar Ecol Prog Ser 254:307-311

> Wickström H, Westin L, Clevestam P (1996) The biological and economic yield from a long-term eel-stocking experiment. Ecol Freshwat Fish 5:140-147

Proofs received from author(s): January 7, 2014 